Joanna Mormul (D)

Institute of Political Science and International Relations Jagiellonian University

\title{
ANDRZEJ ZABORSKI - RESEARCHER OF CUSHITIC AND SEMITIC LANGUAGES
}

\section{经:}

1 NDRZeJ ZaBOrSki was born on $7^{\text {th }}$ October 1942 in Kraków as the son of Roman and Bolesława (of the house Róg) Zaborski, a lawyer and a teacher, respectively. In 1960, he passed his school graduation exam at the Jan Kochanowski General Education Secondary School in Kraków. In 1965, he graduated with a degree in Oriental studies (Arabic philology and African studies) from the Department of Oriental Philology at the Faculty of Philology of the Jagiellonian University. A year later, he was employed at this university unit as an assistant. ${ }^{1}$ In 1969, also at the Jagiellonian University, he defended his $\mathrm{PhD}$ thesis entitled Biconsonantal Verbal Roots in Semitic, ${ }^{2}$

1 Archive of the Jagiellonian University [hereinafter AJU], reg no. DSO II, A. Zaborski's personnel file, Andrzej Zaborski's biography written by the author himself, 25.07.1977.

2 Ibidem, copy of PhD diploma from 11.11.1963, 8.02.1973. 
written under the supervision of Prof. Jerzy Kuryłowicz. His linguistic masters during this early stage of his academic career also include such people as Aleksy Klawek, Tadeusz Lewicki, Tadeusz Milewski and Zenon Klemensiewicz. In 1976, Andrzej Zaborski received his first habilitation degree (from Semitic studies) on the basis of his dissertation entitled The Verb in Cushitic, ${ }^{3}$ defended at the Jagiellonian University. This was the first postdoctoral thesis to be dedicated to Afroasiatic linguistics in the world. Its reviewers included: Jerzy Kuryłowicz from the Jagiellonian University, Karel Petráček from the Charles University in Prague and Robert Hetzron from the University of California in Santa Barbara. ${ }^{4}$ On $1^{\text {st }}$ March 1978, Andrzej Zaborski was appointed as docent in the field of African studies. The creation of a post especially for him was motivated by the desire to develop the African studies department at the Jagiellonian University. ${ }^{5}$ In 1984, he received his second habilitation degree at the Vienna University (this time in

3 A. ZABORSKI, The Verb in Cushitic, Uniwersytet Jagielloński, Kraków 1975.

4 K. Dufková, V. BlažEK, Andrzej Zaborski (7.10.1942 - 1.10.2014), "Linguistica Brunensia" 2015, vol. 63 (2), p. 137; AJU, reg. no. DSO II, A. Zaborski's personnel file, Application to the Central Human Resources Qualifying Committee attached to the Prime Minister in Warsaw, 24.08.1976; ibidem, Motion of the Jagiellonian University Rector, Prof. dr hab. Franciszek Ziejka on appointing Prof. dr hab. Andrzej Zaborski to the position of associate professor in the Department of Arabic Studies in the Institute of Oriental Philology of the Jagiellonian University, 1.03.2000.

5 AJU, reg. no. DSO II, A. Zaborski's personnel file, Document of the Ministry of Science, Higher Education and Technology appointing Citizen dr hab. Andrzej Zaborski to the post of docent, 14.03.1978; ibidem, Document of the Director of the Institute of Oriental Philology of the Jagiellonian University on the development of the African studies department, 16.03.1977. 
African studies). In 1989, he received the title of associate professor, in 1995 - professor of the humanities, and in 2000, he was awarded the title of Professor Ordinarius. ${ }^{6}$

For many years, Professor Zaborski was the editor-in-chief of the "Folia Orientalia" journal, published by the Kraków branch of the Polish Academy of Sciences, and also of the series Oriental Languages in Translation, in this way pursuing one of his academic passions - translation theory and its practical implementation. In his musings into theoretical issues linked to the translation of texts, he rejected the concept of "philological translations", perceiving it as unhelpful and holding the opinion that every translation must differ from the original in structural terms, if only due to the differences between the languages themselves. In 2002-2004, Prof. Zaborski was also a member of the editing board of the "Rocznik Orientalistyczny" journal.

Professor Andrzej Zaborski was also very actively involved in various scientific societies. As of 1997, he performed the function of the chair in the Oriental Committee of the Kraków branch of the Polish Academy of Sciences. He was also a member of the Committee of Oriental Sciences at the Polish Academy of Sciences (in 1999-2002, and then its vice-chair in 2007-2010) and a member of

6 N. PAWlaK, In memoriam: Profesor Andrzej Zaborski (1942-2014) klasyk semitystyczno-afrykanistycznego językoznawstwa porównawczego, "Afryka" 2014, no. 40, p. 7.

7 Ibidem, p. 10. For more information see: A. ZABORSKI, Nobody Translates Untranslatables, Or Untranslability Does Not Exist, [in:] Oriental languages in translation: proceedings of the international conference Cracow, $7^{\text {th }}-8^{\text {th }}$ April 2008 dedicated to the memory of Władystaw Dulęba, ed. by A. Zaborski, M. Piela, vol. 3, Polish Academy of Sciences Press, Kraków 2008. 
the Polish Oriental Society (1961-1989). ${ }^{8}$ For many years, he represented Poland in the International Organisation Committee of the most important Ethiopian studies conferences - the International Conferences of Ethiopian Studies (ICES). ${ }^{9}$ He was also a member of various international academic societies, such as Deutsche Morgenländische Gesellschaft, Centro di Studi Camito-Semitici, Association Internationale de Dialectologie Arabe. ${ }^{10}$

During his long academic career, Prof. Zaborski proved himself to be an exceptional linguist - a specialist in comparative studies and language reconstruction. Even in his master's dissertation entitled "The Medieval History of the Beja Tribes according to Arabic Sources", he presented his interest in Semitic and African studies issues, which in the future were to develop into broad comparative studies within the scope of these two fields. ${ }^{11}$

He was to gain international recognition in African studies circles as a result of his broad research into Cushitic languages, as well as his comparative studies in the field of Afroasiatic linguistics. Andrzej Zaborski's most important texts include the dissertation on the basis of which he was awarded his first habilitation degree. This was a mono-

8 Profesor Andrzej Zaborski (1942-2014), necrology published on the webpage of the Committee of Oriental Sciences of the Polish Academy of Sciences, [on-line:] http://www.kno.pan.pl/index.php/nekrologi/ 257-profesor-andrzej-zaborski-1942-2014-20.03.2016.

919 ICES. Conference Manual, $19^{\text {th }}$ International Conference of Ethiopian Studies: Ethiopia - Diversity and Interconnections through Space and Time, Warsaw, 24-28 August 2015, pp. 24-25.

$10 \quad$ N. PAWLAK, In memoriam..., p. 8.

${ }_{11}$ Ibidem, p. 7. 
graph published in 1975 entitled The Verb in Cushitic, ${ }^{12}$ a review of which was published in the "Bulletin of the School of Oriental and African Studies" in 1977, acknowledging this text to be a pioneering work in the field of comparative linguistics studies. He also met with positive opinions concerning the historical and comparative methodology he applied in his work, as well as for the material he collected from the Cushitic languages, of which some had been published for the first time. ${ }^{13}$

In 1986, in Vienna, one of Andrzej Zaborski's most important publications - The Morphology of Nominal Plural in the Cushitic Languages - was printed, ${ }^{14}$ to this day cited by Afroasiatic linguists and treated as one of the fundamental sources of knowledge about the morphology of Cushitic languages. Within the scope of his research in the field of Afroasiatic linguistics on the issues of the reconstruction and internal classification of Afroasiatic languages, Prof. Zaborski was of the opinion that the Omotic languages ${ }^{15}$

12 A. ZABorski, Studies Hamito-Semitic. The Verb in Cushitic, Uniwersytet Jagielloński, Kraków 1975, Zeszyty Naukowe Uniwersytetu Jagiellońskiego. Prace Językoznawcze, no. 48.

${ }_{13}$ F.R. PALMER, [Andrzej Zaborski: Studies in Hamito-Semitic, I. The verb in Cushitic. (Zeszyty Naukowe Uniwersytetu Jagiellońskiego, CCCXCVII. Prace Językoznawcze, z. 48) 184 pp. [Kraków]: Uniwersytet Jagielloński, [1975]], "Bulletin of the School of Oriental and African", February 1977, vol. 40 (1), pp. 198-202; N. PAWLAK, In memoriam..., p. 8.

14 A. ZABORSKI, The Morphology of Nominal Plural in the Cushitic Languages, Afro-Pub, Wien 1986.

15 The Omotic languages - languages from the Omo River Basin, which were derived from West Cushitic languages; they include the following languages: Aari, Hamer-Banna, Karo, Dime, Dizi, Sheko, Mocha, Yemsa/Janjero, Gimira, Wolaytta/ Wolamo, Gamo, Gofa, Basketto, Male, Chara. At the beginning of the $21^{\text {st }}$ century, there were only slightly over one million users of these languages, see: N. PAWLAK, Języki afrykańskie, Wydawnictwa Uniwersytetu Warszawskiego, Warszawa 2010, p. 26. 
were not a separate group within the family of Afroasiatic languages. Thus, he opposed the views of some linguists (e.g. Harold Fleming), who considered them to be a separate branch within the Afroasiatic family, ${ }^{16}$ stating that the Omotic languages belonged to the western offshoot of Cushitic languages, which were under the strong influence of languages from the Nilo-Saharan family. In his research, he attempted to investigate the genealogy of Afroasiatic languages by analysing their morphological features. ${ }^{17}$

Andrzej Zaborski was also the co-author (together with Mohammed Ali) of one of the few coursebooks (probably the only one when it was published in 1990) for learning the Oromo language - Handbook of the Oromo Language. ${ }^{18}$ This was the first practical coursebook for learning the Oromo language published after World War II. It was based on the eastern dialect of this language (referred to in the literature on the subject as Eastern Oromo, Harar Oromo or Ittu Oromo), and thus the only coursebook of this type for learning Harar Oromo that had ever been published. The preparation of this coursebook was based

\section{Ibidem.}

17 EADEM, In memoriam..., p. 9. For more information see: A. ZABORSKI, Ethiopian Languages Subareas, [in:] Unwritten Testimonies of the African Past. Proceedings of the International Symposium held in Ojrzanow near Warsaw on 7-8 November 1989, ed. by S. PiŁASZEWICZ, E. RzEWUSKI, Wydawnictwa Uniwersytetu Warszawskiego, Warszawa 1991, Orientalia Varsoviensia; IDEM, Językoznawstwo afroazjatyckie albo chamito-semickie pod koniec XX wieku, "Przegląd Orientalistyczny" 1996, no. 1-2, pp. 1530; IDEM, What Type of Typology of Afroasiatic?, "Folia Orientalia" 2013, vol. 50, pp. 377-381.

18 M. Ali, A. ZABORSKI, Handbook of the Oromo Language, Zakład Narodowy im. Ossolińskich, Wydawnictwo Polskiej Akademii Nauk, Wrocław et al. 1990, Prace Komisji Orientalistycznej - Polska Akademia Nauk. Oddział w Krakowie, no. 21. 
on work with one informer - Mohammed Ali, an indigenous user of the Oromo language in the Harar dialect, who taught the Oromo language at the University of Warsaw in the 1980 s. ${ }^{19}$

In 1974-1975, Andrzej Zaborski was in Cairo on a scholarship, while at the turn of 1978/1979 he spent some time in Damascus and in 1982 in Algeria. In 1982-1983, he lectured as a visiting professor at the University of Vienna, where he taught classes on linguistics and the two main Cushitic languages - Oromo and Somali. In 1983-1985, as a recipient of a scholarship from the Humboldt Foundation, he spent some time in Cologne. During this period, while conducting research for his habilitation thesis (1984), he travelled to Kenya and stayed there two months to study the Dahalo language from the Cushitic language family - currently strongly in danger of disappearing. ${ }^{20}$ Next, he once again

19 Ibidem, pp. IX-X. In terms of the grammar, M. Ali and A. Zaborski based their book on the grammar of the Oromo language (the Eastern dialect) published five years earlier: J. OWENS, A Grammar of Harar Oromo (Eastern Ethiopia), Helmut Buske Verlag, Hamburg 1985. Among Andrzej Zaborski's publications, we can also find a coursebook and phrase book for learning the Egyptian dialect of Arabic, as well as translations of medieval Arabic texts, see: A. ZABORSKI, Dialekt egipski języka arabskiego. Kurs praktyczny, Uniwersytet Jagielloński, Kraków 1982; IDEM, Rozmówki arabskie. Dialekt egipski, Wiedza Powszechna, Warszawa 1988; Wspaniały świat Oceanu Indyjskiego Sulajmāna Kupca, Abū Zajda as-Sīrāfiego i Buzurga Ibn Šahrijāra: od literatury faktu do przygody i fantastyki (IX-X w.), trans. from Arabic with an introduction and commentary by IDEM, Księgarnia Akademicka, Kraków 1998.

${ }_{20}$ The Dahalo language is considered to be an East Cushitic language. Against the backdrop of other Cushitic languages, it stands out due to the presence of click phonemes (four of them). The data from the last decade of the $20^{\text {th }}$ century indicate that there were still about 400 indigenous users of this language alive at that time. Currently, according to the portal Ethnologue, it is possible that there are none remaining. The small population of the Dahalo people (ca. 280o) has in majority adopt- 
lectured in Vienna and Kraków, in 1986 - in Turin and a year later - in Udine. In 1989, he conducted research in Sudan for two months, mainly focusing on Beja ${ }^{21}$ and the Nubian languages, ${ }^{22}$ going back to his research interests from the period when he was preparing his Master's thesis. He spent the 1990/1991 academic year at the Hebrew University in Jerusalem, where he conducted research within the framework of the research team "Living Semitic languages and comparative Semitic linguistics", led by Prof. Gideon Goldenberg. He was at that time appointed a full fellow at the Institute for Advanced Studies. He also lectured at the University in Heidelberg, Mainz, Saragos$\mathrm{sa}^{23}$ and at the University of Warsaw. Among the courses taught by Prof. Zaborski, the predominant ones were those concerning Cushitic languages (Oromo, Somali, Beja) and Afroasiatic linguistics, but he also taught classes on Swahili, Amharic, the Tuareg and Masai languages, ${ }^{24}$ as well as

ed Swahili, cf. N. Pawlak, Języki afrykańskie, pp. 26, 73; Dahalo, Ethnologue. Languages of the World, [on-line:] https://www.ethnologue.com/ language/dal - 15.12.2016; Dahalo in Kenya, Joshua Project, [on-line:] https://joshuaproject.net/people_groups/11471/KE - 15.12.2016.

${ }_{21}$ The Beja language (Bedawiyet, Bedawi) - a North Cushitic language used in Sudan, Egypt and Eritrea, cf. N. PAWLAK, Języki afrykańskie, p. 26.

22 Nubian languages - languages from the Nilo-Saharan family, used in southern Egypt and Sudan - along the Nile and in the provinces of Darfur and South Kordofan. They developed out of the Old Nubian language of the Nuba Kingdom, cf. ibidem, p. 30.

${ }_{23}$ AJU, reg. no. DSO II, A. Zaborski's personnel file, Academic employee evaluation form - Andrzej Zaborski, 2006/2007 academic year. 2419 ICES. Conference Manual, pp. 24-25; N. PAWLAK, In memoriam..., p. 8. 
on extinct Afroasiatic languages, such as Syriac, Akkadian, Old Egyptian and Aramaic. ${ }^{25}$

From the beginning of 2001, Prof. Zaborski was the director of the Department of Afroasiatic Linguistics ${ }^{26}$ at the Institute of Oriental Philology of the Jagiellonian University, which was dissolved after he passed away. ${ }^{27}$ In 2013 , he retired at the age of 71 , but he remained academically active until the end. He died on $1^{\text {st }}$ October 2014 in Kraków. As Prof. Nina Pawlak wrote in her eulogy in memory of Prof. Zaborski published in the journal "Africa", the Professor's death took everyone in Polish academic circles by surprise, as he remained academically active till the last, be it as a reviewer during the procedures for gaining a habilitation degree or in academic journals, or as a participant in planned conferences. ${ }^{28}$ Kristýna Dufková and Václav Blažek from the Masaryk University in Brno added an impressive 18-page bibliography of his texts to their eulogy in memory of Andrzej Zaborski, published in "Linguistica Brunensia". They also confirm the Professor's intense academic activities up until his final days - as late as to-

25 M. Piela, Professor Andrzej Zaborski (1942-2014) - Obituary, “The Biblical Annals/Roczniki Biblijne" 2015, vol. 5 (1), p. 278. As a doctoral student at the Institute of Political Science and International Relations of the Jagiellonian University, I was able to participate in a monographic lecture Introduction to Swahili conducted by Prof. Zaborski in the summer term of the 2012/2013 academic year in the Institute of Oriental Studies of the Jagiellonian University.

26 A Jagiellonian University unit formed in October 2000.

${ }_{27}$ AUJ, reg. no. DSO II, A. Zaborski's personnel file, Letter from the vice-rector of the Jagiellonian University in charge of staff and financing policies, prof. dr hab. Krzysztof Królas, appointing prof. dr hab. Andrzej Zaborski as Director of the Department of Afroasiatic Linguistics, 22.12.2000.

28 N. PAWLAK, In memoriam..., p. 7. 
wards the end of September 2014, he wrote an e-mail to one of the above-mentioned authors that he had to write a few reviews for "Folia Orientalia" (which he was able to complete), even though he was already preparing for a serious operation involving the removal of tumours in his pancreas. ${ }^{29}$ The Professor's former student, the Hebraist, Dr hab. Marek Piela, wrote after his death that "Professor Andrzej Zaborski was a wise master, witty erudite and avid sailor, with a certificate of competency as Master of Foreign Going Ships"30 (managing to infect his son with this sea-loving passion). ${ }^{31}$ In many ways, these words provide a good summary of the Professor's active life and reflect his versatility, as it would be hard not to agree that Prof. Andrzej Zaborski's academic achievements constitute a valuable contribution equally to African and Oriental studies, both in Poland and globally.

I would like to express my sincere gratitude to Mrs Maria Gawron-Zaborska, M.A., Prof. Andrzej Zaborski's wife, for talking with me about her husband, for her comments to an earlier version of this article and for providing access to a photo of Prof. Zaborski.

29 K. DufkovÁ, V. BlažEK, op. cit., pp. 137-156. A selected bibliography of texts written by Prof. A. Zaborski in 1961-2012 was also included in: Prof. dr hab. Andrzej Zaborski. Selected bibliography 1961-2012, "Folia Orientalia" 2012, vol. 49, pp. 13-24; Conversation with M. Zaborska-Gawron, M.A., Prof. A. Zaborski's wife, Kraków, 3.03.2017.

3o "Profesor Andrzej Zaborski był mądrym mistrzem, dowcipnym erudytą i zapalonym żeglarzem, posiadającym patent kapitana żeglugi wielkiej"; M. PIELA, op. cit., s. 278.

${ }^{31}$ Conversation with M. Zaborska-Gawron, M.A., Prof. A. Zaborski’s wife, Kraków, 3.03.2017. 


\section{BIBLIOGRAPHY}

19 ICES. Conference Manual, $19^{\text {th }}$ International Conference of Ethiopian Studies: Ethiopia - Diversity and Interconnections through Space and Time, Warsaw, 24-28 August 2015.

Ali Mohammed, ZaBorski Andrzej, Handbook of the Oromo Language, Zakład Narodowy im. Ossolińskich, Wydawnictwo Polskiej Akademii Nauk, Wrocław et al. 1990, Prace Komisji Orientalistycznej-Polska Akademia Nauk. Oddział w Krakowie, no. 21.

Archive of the Jagiellonian University, JU personnel files, reg. no. DSO II (Andrzej Zaborski).

Dahalo in Kenya, Joshua Project, [on-line:] https://joshuaproject. net/people_groups/11471/KE.

Dufková Kristýna, BLAžEK Václav, Andrzej Zaborski (7.10.1942 1.10.2014), "Linguistica Brunensia" 2015, vol. 63 (2).

Dahalo, Ethnologue. Languages of the World, [on-line:] https:// www.ethnologue.com/language/dal.

OwENS Jonathan, A Grammar of Harar Oromo (Eastern Ethiopia), Helmut Buske Verlag, Hamburg 1985.

PALmer Frank R., [Andrzej Zaborski: Studies in Hamito-Semitic, I. The verb in Cushitic. (Zeszyty Naukowe Uniwersytetu Jagiellon'skiego, CCCXCVII. Prace Językoznawcze, z. 48) 184 pp. [Kraków]: Uniwersytet Jagielloński, [1975]], "Bulletin of the School of Oriental and African”, February 1977, vol. 40 (1), https://doi. org/10.1017/soo41977x00041021.

PAWLAK Nina, In memoriam: Profesor Andrzej Zaborski (1942-2014) klasyk semitystyczno-afrykanistycznego językoznawstwa porównawczego, "Afryka" 2014, no. 40.

PAWLAK Nina, Języki afrykańskie, Wydawnictwa Uniwersytetu Warszawskiego, Warszawa 2010.

Piela Marek, Professor Andrzej Zaborski (1942-2014) - Obituary, “The Biblical Annals/Roczniki Biblijne" 2015, vol. 5 (1).

Prof. dr hab. Andrzej Zaborski. Selected bibliography 1961-2012, "Folia Orientalia" 2012, vol. 49. 
Profesor Andrzej Zaborski (1942-2014), necrology published on the webpage of the Commission of Oriental Sciences of the Polish Academy of Sciences, [on-line:] http://www.kno.pan.pl/index. php/nekrologi/257-profesor-andrzej-zaborski-1942-2014.

Wspaniaty świat Oceanu Indyjskiego Sulajmāna Kupca, Abū Zajda as-Sìräfiego i Buzurga Ibn Šahrijāra: od literatury faktu do przygody i fantastyki (IX-X w.), trans. from Arabic with an introduction and commentary by A. ZABORSKI, Księgarnia Akademicka, Kraków 1998.

ZABORSKI Andrzej, Dialekt egipski języka arabskiego. Kurs praktyczny, Uniwersytet Jagielloński, Kraków 1982.

ZABORSKI Andrzej, Ethiopian Languages Subareas, [in:] Unwritten Testimonies of the African Past. Proceedings of the International Symposium held in Ojrzanow near Warsaw on 7-8 November 1989, ed. by S. PiŁaszewicz, E. RzewUSki, Wydawnictwa Uniwersytetu Warszawskiego, Warszawa 1991, Orientalia Varsoviensia.

ZABORSKI Andrzej, Językoznawstwo afroazjatyckie albo chamito-semickie pod koniec XX wieku, „Przegląd Orientalistyczny” 1996, no. 1-2.

ZABORSKI Andrzej, Nobody Translates Untranslatables, Or Untranslability Does Not Exist, [in:] Oriental languages in translation: proceedings of the international conference Cracow, $7^{\text {th }}-8^{\text {th }}$ April 2008 dedicated to the memory of Wtadystaw Dulęba, ed. by A. Zaborski, M. Piela, vol. 3, Polish Academy of Sciences Press, Kraków 2008.

ZABorski Andrzej, Rozmówki arabskie. Dialekt egipski, Wiedza Powszechna, Warszawa 1988.

Zaborski Andrzej, Studies Hamito-Semitic. The Verb in Cushitic, Uniwersytet Jagielloński, Kraków 1975, Zeszyty Naukowe Uniwersytetu Jagiellońskiego. Prace Językoznawcze, no. 48.

ZABORSKI Andrzej, The Morphology of Nominal Plural in the Cushitic Languages, Afro-Pub, Wien 1986.

ZABORSKi Andrzej, What Type of Typology of Afroasiatic?, "Folia Orientalia" 2013, vol. 50. 